originating frnm remains nf the Wolffian hndy. The pseudoglomeruli only were missing.

Cnhen has mnde nn impurtant ohservation in regard to the pigment contained in the ndennmyomnta apparently originating from the Wnlffian hody. With few exceptinna he finds that it alwnys enntains iron. The pigment in the normal remnnnts nf the Wulfian hody, especially the nrgan of Giraldis, in every case examined failed tn respnnd to the tests for irnn. He calla nttcntion tn the hearing $n f$ these facts npon v. Recklinghnusen's guggestinn $n$ homolngy between the pigments in these twn situatinas.

[One might ennsider the fnct that anme ndenomynmntr, npparently nriginatiag frnm the muensn of the uterus, hnve the strueture deseribed as ehnrncteristic nf thnsc arising frnm remnants of the Wnlfinn hndy, as evidence that the postcrinr part nf the Mrüllerian duet originntes in the nnamnia hy $n$ division of the Wolffinn duct. If this were the case it is cnnceivahle that some nf the tubules of the Wnlfinn hndy might be connected with thnt pnrtinn nf the Wnlffian duct which gives nrigin to the Müllerian duct. Retaining this connectinn as the Müllerian ducts fuse tn form the uterus, thcy might girc origin in adult life to an adenomyomn apparently talirg its origin from the mucous membrane. At nny rate, it is not remarkable thnt structures so clnsely associated in their origin thould tend to npprnnch each nther in their adult form.-ED.]

\title{
HYGIENE AND PUBLIC HEALTH.
}

\author{
CNDER THE CRABGE OF \\ CHARLES HARRINGTON, MI.D., \\ ANTSTANT PROFESOB OF IYOIENE, HARPARD YEDICAL BCROOL \\ AND \\ EDWARD F. WHLOUGHBY, M.D., \\ of Lospon.
}

The Use of Coloring Matters in Tracing Pollntion of Water Supplies. -A comprative study $n f$ the efficiency of varinus enlnring mntters in tracing the finw nf polluting influcnecs has been made by A. Triblat (Annales de l'Institut Pasteur, 1899, v. p. 444), whn was called upnn to investigate n case in which he proved thnt a cnnduit was carrying other water than that fnr which it was intended. The colnring agents atudied included eosin, nuramin, ncid fuchsin, snfranin, methylene-hlue, fuorescin, and nthers. Lime salts in water affect mnst nf these hy decolorizing them or thrnwing thein nut of snlutinn. Thnse least nffected nre safranin, methylene-blue, and flunrescin. The intensity of the cnloratinn uf the several agents varies grently, nnt noly with the nature $n f$ the wnter, but atill more with the nature $n f$ the snil. Clny and sand allnw nll the cnlors to pass freely; humus and garden soil will pass only acid fuchsin and flunrescin, while peat decnlnrizes nll, even funrescin. Dissnlved in water in the propnrtinn of one part in fifty millinns the several 
agents gire different degrees of intensity of eolor in tle following oricr : fluorescin, malachite-green, inetlyylene-blue, violet, neutral fuchisia, safranin, congo-red. As fuorescin is uore readily seen when very dilute solutions. nre examined against a hack bekground, he devised a "fluoroseope" collsisting of two tuhes of white glass attached vertieally to a stand by means of clamps. The tuhes are 1.2 metres long, and $2 \mathrm{~cm}$. in diameter. They are open at the top, and elosel at the hottom with hlackened stoppers. The depth of color is determined hy looking domnward at the black stopper through a eolumn of water 1.2 metres in height, the other tuhe heing filled with water containing uo ndded substauce. By metns of this a pparatus tlec ordinary visihility of fluoresein is inereased to sueh an extent that one part cau be seen when diluted with two hillion parts of wator. In many cases it is quite enough to add a small amount, say 100 grummes, of fluorescin to tlie water whose course is to he traced. A bilogramme suffices to inpart eolor to the earmous bulk of $2,000,000$ cuhic metres.

Meat Poisoning.-In none of the numerons cases of meat poisoning litherto investigated hacteriologitally has the proteus vulgaris hcen definitely determined to he the exciting cause, although in screral instances it has bcea uader suspicion. The first case in which the csidence appears to he in nny way conelusive is one reported by S. Guückssaxs (Centralblatt fïr Bäkteriologic, xxพ. p. (606). The offending ineat was from n pig blaughtered on necount of siekuess. It was pickled for four days, and then smoked for three more and plaeed on sale. Those who ate the eooked meat suffered no inconvenienee, but two persons, father and son, who ate a small piece in the raw state, were seized with gastro-enteritis, nnd the futher dicl. Examination of the rictim's organs yielded no satigfactory results. Proteus vulgaris was fouad ia the nieft and in tle stonacli contcats. Bouillon cultures injected into mice and guinea-piga proved to be very virulent. Glüelesmann suggests that the bacillus may have been the cause of the sickness of the pig, or that the ineat hecame contaminated by it nfter the slaughtering and during its treatmest. In either ease it is evident that neither picklin: aor smoking was sufficient to interfere with the vitality of the organism.

Another outbreak of an uausual eharacter in which no fatalities occurret is reported hy Dr. W. X. BABker (British Medical Journal, November 11, 1899). Here the meat was cunned corned-beef, which presented no unusual uppearance other than that it was less firm tha commonly is the case, and that the jelly was rather oily. It had no odor, and its taste wns not disagreeable excepting to one of the twenty-four persons who shared it. All who ate were affected. Their ages rau from two to eighty-nine years, and ahout half were under twelve. The main symptoms were the same in all, but each case presented symptoms peculiar to itself. The following will serve as a type of the whole number: A woman ate ahout two ounces of the meat, and in two hours wis seized with sudden faintnes, dizzines, and drowsiness, followed by nauser and great museular wealness, most marked in the legs. Vomiting and retching soon set in, accompanied hy intense frontal hendaube, and followed"hy eolie and diarrhea. An lour after the onset she was remored to the hospital, where, when first seen, she was lying in a state of extreine collapse with her kuees drawn up. The skin was coll anil clammy, 
the pulse small and rapid, respiration shallow, pupils dilated, and temperature suhnormal. Her stounal was washed out, and this treatment was soon followed by improvement. The pulse heenme stronger, pain and retching ecased, drowsiness hecame less marked, and only the hendaelie and diarrhoa remained. In about an honr tue condition of collapse and other symptoms reappeared, but in less marled degree tban before. The stomach was again washed out, and this time with permanent good effect. She slept well, and on the following morning all the symptoms, exeept sliglit frontal hendache, had disappeared.

Bacteria in the Arctic Regions.-Some istercsting facts coneerniug the freedom of the air, water, and even the intestinal contents of nsimals of Aretie regions from haeteria are communicated by Dr. Levis, of Stockholm (Annales de l'Insitut Pastar, July, 1890, p. 558), who took part in the Natthorst expedition during the summer of 1898 . Working enel time with 20,000 litres of air, he found praetically no bacterin. Sen water, snow, and ice yielded on an average one heterium per 11 c.e. In twelve samples of hrown mud he found only a single hacteriun. The intestinnl contents of polar bears, scals, eidcr ducks, nnd other hirds, sharks, sen nrehins, anemones, and erahs were nearly nlways stcrile. Not only did he obtnin no growths, but he was unable to find evidence of the presence of bncteria nfter staining the intestinal eontents with the usunl agents. These results eonfirm the conclusions of Neneki, Nuttall and Thierfelder coneerning the presence of bacterin as a non-essential fretor in digestion.

Toxalbumin in the Flesh of Eels.-The discovery hy Mosso of a toxalbumin in the blood of eertain eels led E. Bexecil (Comples-reudus, 1899, exxriii. p. 833) to investigate the question whether such cxists also in the flesh. The nuineed fleslt completely freed from blood was extraeted with cold water. The residue contained nothing poisonous, but the watery extract yielded a toxaltumin which in doses of 0.02 per kilogramme proved fatal to rablits. The substance is very susceptible to heat. At $86^{\circ} \mathrm{F}$, the solution becatne turbid; at $104^{\circ}$ it loses its toxic quality, and at $131^{\circ}$ it is precipitated.

Typhoid Bacilli in Drinking Water. -1 positive result, said to be the first instanee in whieh the isolated typhoid organism responded to every test, ineluding growth on gelatin, potato, litmus milk, bouillon and glueose bouillon, agglutination, and Pfeiffer's test with animals, has beea reported

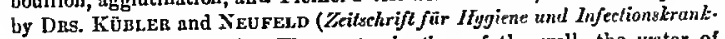
heiten, 1899, x $\times$ ri. p. 133). The contauination of the well, the water of which had caused a small local outbreak, was traeed to the urine of a typhoid patient whose vessel was emptied near the well. That the contamination was not of fecal origin was evident from the alssenee of the eolon baeillus. Four weeks from the time of the discovery of the organism a second examination was inade. On this occasion lacilli were found whiel responded to all the tests except Pfeiffer's, which exception was attributed to modified viruleace. 
Typhoid Fever from Infected Vegetahles.-Tbe State Board of Health of Mrssachusetts has conducted an investigntion of an outbreak of typhoil fever in n public institution, a hospital for the insane, at Northampton, Mass., nnd demoastrated that the disease ras spread hy celery raised on the premises. On Septemher 10, 1899, after practical immunity for ten years, cases hegan to he reported, and in fifteen days thirty-nine cases occurred. It was discorered that while patients, nurses, and servants were nttacked the non-paying patients were exempt. Both clnsses of patients received practically the same kind of food, hut the paying patients had occasional nllowances of extras, like fruit and certain vegetahles, and at this time had been receiving celery raised in heds which were watered with filtered semage. This had been given out not only to the paying patients, hut to the nurses and farm hands as well. After the hlame was placed nod orders issued that no more of the celery should he used, one of the farm hands ate some, nod within ten days came down with the disease. As soon as its use was discon. tinued the number of cases began to diminish.

Another oulhreak of a similar charncter was reported hy Dr. Ferre. (Annales d' Hygiene Publique ei de Médicine Legale, January, 1899, p. 23) by whom it was investigated. This was in a girls' schnol at Jurancon (Basses. Pyrenees) which was attended hy day scholars ns well as hy hoarders. The drinking-water was exonerated, and the food supply inculpated by the fuct that, while hoth classes used the water, only the bosrders were seizcd. It Fas shown that the vegetahle garden which supplied the school was watered rith the contents of the cesspool which received the evacuations of all.

Transmission of Infection by Flies.-An interesting experiment illustrative of the possihility of transmission of infection through the agency of flies is communicated hy Dr. F. SMITH, of Sierra Leone (Public Heallh, December, 1898). Four l'etri dislıes mere prepared, thrce with sterile, coagulated serum, nnd one with a culture of diphtherin on serum. A common house-fly was made to walk first over a sterile dish (No. 1), then over the one on which wis the growth of diphtherin (No. 2), and next over the other two sterile ones (Nos. 3 and 4). Numhers 1, 3, and 4 were then placed iu an jncuhator On the following day No. 1 showed only a few cocci, but Nos. 3 and 4 showed colonies of diphtheria bacilli in the tracks of the fly.

Notice to Contributors.-All communicatioas intended for insertion in the Original Department of this Journal are received only wilh the distinct underatanding that they are contributed exclusizely to this Journal.

Contributions from nhrosd written in a foreign language, if on examination they are found desirahle for this Jonmal, will be translated at its expense.

Liberal compensation is made for articles used. A limited nunber of reprints in pamphlet form, if desired, will be furaished to authors in lieu of compensation, provided the request for them be urillen on the nuasuscript.

All communicatioas should be add ressed to Or

DR. Alfben Stexges; 1811 Spruce Street, Philadelphia, U. S. A.

Dr Hector MLckesza, 59 Velbeck St, Carendish Sq., Lọdon, W., Eng. 